\title{
Response of a freshwater air-breathing fish, Clarias batrachus to salinity stress: an experimental case for their farming in brackishwater areas in Andaman, India
}

\author{
Kamal Sarma $\cdot$ K. Prabakaran • P. Krishnan • G. Grinson • \\ A. Anand Kumar
}

Received: 30 August 2011/ Accepted: 2 May 2012

(C) Springer Science+Business Media B.V. 2012

\begin{abstract}
The study was conducted to assess the effects of salinity on growth and biochemical composition of freshwater catfish, Clarias batrachus. A static nonrenewable acute toxicity bioassay test was conducted and $\mathrm{LC}_{50}$ of salinity for $96-\mathrm{h}$ exposure to the fingerling $(14.5 \mathrm{~cm})$ was $12.52 \%$. Based on these results, two sublethal salinity levels, viz. 4 and $8 \%$ were selected to study the long-term effects of salinity on C. batrachus for a period of 90 days. From the study, it was found that growth and survival rate were less in saline water (4 and $8 \%$ ). Maximum growth and survival were recorded in freshwater ( $0 \%$ salinity) and subsequently at 4 and $8 \%$. To assess the biochemical alteration, few important biomarkers were estimated. At the end of 90 days rearing period, glucose level in the brain and blood of C. batrachus was found to decrease with salinity. The level of liver and muscle glycogen in the fish reared at $4 \%$ was lower than that of control. Ascorbic acid in all organs under study was found to decrease with increasing salinity, which was attributed to stress mitigation effect of vitamin C. Acetylcholine esterase (AchE) activity recorded a gradual decrease with increasing salinity. Metabolic enzymes, alkaline phosphatase (ALP) activity and adenosine triphosphosphtase (ATPase) activity also reduced both in liver and muscle tissues with increasing salinity. From the present investigation, it can be concluded that exposure to higher salinity significantly $(P<0.01)$ affects the growth and physiological response of Clarias batrachus.
\end{abstract}

Keywords Ascorbic acid $\cdot$ Glucose $\cdot$ Stress $\cdot$ Enzyme $\cdot$ Catfish

\section{Introduction}

Salinity tolerance limits of freshwater fishes are of ecological significance in assessing the distribution of fish and their impact on ecosystems (Kilambi and Zdinak 1980). It is an important environmental factor, which influences growth performance of many fish

K. Sarma $(\bowtie) \cdot$ K. Prabakaran · P. Krishnan · G. Grinson · A. Anand Kumar Marine Research Laboratory, Division of Fisheries Science, Central Agricultural Research Institute, ICAR, Post Box No 181, Port Blair 744 101, Andaman and Nicobar Islands, India e-mail: kamalsarma6@rediffmail.com 
(Kang'ombe and Brown 2008). Salinity effects have been studied in several species of fish in ponds, tanks, raceways and cages (Cruz et al. 1990; Watanabe et al. 1990). Fluctuation of salinity is very pronounced in tropics where the climate is characterized by wet and dry seasons (Suresh and Lin 1992; Boyd and Tucker 1998). In Western Australia, salinity in farm ponds fluctuates from less than $0.5 \%$ in the wet season to over $3 \%$ in dry season (Boyd and Tucker 1998). Especially in island conditions like Andaman, where annual average rainfall is over $3,000 \mathrm{~mm}$, pond water salinity changes due to high precipitation during monsoon and high evaporation during the dry season. Therefore, it is important to understand the salinity tolerance of freshwater fish species in areas where sea water intruded.

Clarias batrachus is a freshwater Indian catfish popularly known as magur. It is well distributed in Indian subcontinent (Jayaram 1981) fetching very high price in the domestic market (Das 2002). They are obligatory air breathers and normally inhabit in low lying water bodies, swamps, marshy and derelict waters, rivers, etc. (Chondor 1999). They are very hardy in nature (Kumar et al. 2012, Verma et al. 2011) and can thrive in adverse ecological conditions like vey low dissolved oxygen, high turbidity, etc. Clarias batrachus is an omnivore fish having broad feeding habits at different life stages (Hora and Pillay 1962). However, in recent times, the magur population has decreased at an alarming rate due to high fishing pressure as well as habitat destruction (Sahoo et al. 2010; Khedkar et al. 2010) and has become a vulnerable species (CAMP 1998).

During the tsunami in 2004, a large portion of coastal areas of Andaman and Nicobar islands (ANI) was completely submerged by seawater (Raja et al. 2009). Total cultivated land available before the tsunami was 50,000 ha that came down to 43,339 ha (Sarma et al. 2010a), and area under paddy has drastically come down from 12,000 ha to less than 8,000 ha due to submergence of low lying areas or seawater intrusion (Deshmukh and Din 2008). Due to salination of freshwater, many freshwater species might be under severe stress and threat due to their inability to cope up with extreme physiological and osmotic stress. Biochemical constituents and enzymes have been explored as potential biomarkers for variety of organisms as these parameters are highly sensitive and conserved between species and less variable (Agrahari and Gopal 2009). Hence, there is an urgent need to know the actual physiological consequences of salinity on an organism and also to ascertain whether some of the freshwater species can be farmed in the low saline brackishwater areas. Hence, the present study was undertaken to study the sublethal effect of salinity on growth and biochemical parameters of Clarias batrachus reared under different salinity exposure for a period of 90 days.

\section{Materials and methods}

Experimental animals

Healthy fingerlings of Clarias batrachus were collected from Magur Hatchery unit of Central Agricultural Research Institute (CARI), Andaman. The collected fingerlings were transported in oxygenated bags to the laboratory, located $12 \mathrm{~km}$ away from the hatchery. The fish were acclimatized to the laboratory conditions for a period of 1 week prior to the experiment. 
Treatments

A static nonrenewable acute toxicity bioassay was conducted according to standard method (APHA, 1998 and Reish and Oshida, 1987) to determine LC $_{50}$ concentration of salinity for fingerlings $(14.5 \mathrm{~cm})$ of Clarias batrachus following exposure of $96 \mathrm{~h}$. Initially, range finding test was conducted and recorded mortality percentage of 0 and $100 \%$. Subsequently, definitive test was conducted for four different test media (11 to $14 \%$ ) with 3 replications for each treatment (10 fishes per tank), and the data obtained from the experiment were processed by probit analysis using a personal computer. The median lethal concentration of salinity at the end of 96-h exposure for fingerling $(14.5 \mathrm{~cm})$ was $12.52 \%$. Based on $\mathrm{LC}_{50}$ for $96 \mathrm{~h}$ of $C$. batrachus fingerlings $(12.52 \%$ ), three different sublethal salinities, viz. 0,4 and $8 \%$ were identified to assess the effect of salinity on the fishes. The water quality parameters that were maintained in rearing tanks for the experiment are depicted in Table 1 . Filtered seawater (33\% salinity) was used in preparing desired salinity in the experiment. Freshwater $(\sim 0 \%)$ was collected from municipal supply and stored in separate tanks $(1,0001)$ at least 5 days prior to using them. Before $24 \mathrm{~h}$ of utilization, both freshwater and seawater were collected separately in FRP (fiber reinforced plastic also called fiber reinforced polymer) tanks and vigorously aerated. Required salinity (4 and $8 \%$ ) was made by mixing fresh water with the seawater appropriately.

\section{Experimental design}

Completely randomized design was followed in the present experiment. 90 fish $(14.10 \pm 0.1 \mathrm{~cm} ; 18.96 \pm 0.37 \mathrm{~g})$ were distributed in three different groups with 3 replicates per treatment. Stocking density maintained for the experiment was $10 \mathrm{fish} / \mathrm{tank}$. The experiment was conducted in 2001 identical FRP tanks in which 1501 of water was maintained. Three different salinity treatments, viz. 0,4 and $8 \%$ were selected based on the acute toxicity results, and the rearing experiment was conducted for a period of 90 days. Round-the-clock aeration was provided in all the tanks from a centralized air blower. The uneaten food and fecal matters were removed on daily basis by siphoning. Complete water exchange was done on weekly basis.

Table 1 Average water quality parameters in the rearing tanks of Clarias batrachus for a period of 90 days of culture in different salinities

\begin{tabular}{llll}
\hline Parameters & \multicolumn{3}{l}{ Salinity } \\
\cline { 2 - 3 } & $0 \%$ \% & $4 \%$ \% & \\
\hline Water temperature & $28.23 \pm 0.31$ with a range of $26.4-30.20{ }^{\circ} \mathrm{C}$ & \\
Turbidity & $30.768 \pm 1.57$ & $28.764 \pm 0.078$ & $29.588 \pm 0.254$ \\
DO & $5.118 \pm 0.267$ & $5.206 \pm 0.245$ & $4.966 \pm 0.428$ \\
DO\% & $68.627 \pm 3.32$ & $70.641 \pm 2.41$ & $65.288 \pm 8.07$ \\
pH & $7.954 \pm 0.235$ & $7.836 \pm 0.12$ & $7.912 \pm 0.099$ \\
Salinity & $0.262 \pm 0.064$ & $4.262 \pm 0.09$ & $8.197 \pm 0.034$ \\
\hline
\end{tabular}

Units: temperature $={ }^{\circ} \mathrm{C}$, turbidity $=\mathrm{NTU}, \mathrm{DO}=\mathrm{mg} / \mathrm{l}, \mathrm{pH}=$ hydrogen ion concentration, salinity $=\mathrm{g} / \mathrm{l}$ 
Growth and survival study

Monthly sampling was carried out to ascertain weight gain and survival of the fish using the following formulae:

$$
\begin{gathered}
\text { Weight gain }(\%)=\frac{(\text { final weight }- \text { initial weight })}{\text { initial weight }} \times 100 \\
\text { Survival }(\%)=\frac{\text { Number of fish survived after } 90 \text { days }}{\text { Initial number of fish stocked }} \times 100 \text {. }
\end{gathered}
$$

Feed preparation and feeding

The basal diet was formulated using wheat flour, rice bran, groundnut oil cake, vegetable oil, fish meal, minced meat and vitamin. Minced meat was prepared by finely chopping the flesh portion of dressed mackerel fish. All ingredients, except mineral-vitamin mixture and minced meat, were mixed in a plastic bowl and dough was prepared using water. The dough was then steamed for about $15 \mathrm{~min}$ in a pressure cooker. The vitamin-mineral mixture and minced meat were mixed after cooling. This moist feed was used for feeding fishes at the rate of $5 \%$ body weight per day. Total feed quantity was divided into two parts and distributed in the morning and afternoon hours. The proximate composition of the feed was estimated following Malik and Sirohi (2004) and moisture, crude protein, fat and ash content were found to be $58.18 \pm 2.40 \%, 35.48 \pm 4.84 \%, 4.76 \pm 0.33 \%$ and $4.65 \pm 0.86 \%$ respectively.

\section{Sample preparation}

At the end of 90 days, 6 fish per treatment ( 2 per tank) were taken out, anaesthetized with clove oil $(50 \mu \mathrm{l} / \mathrm{l})$ and different organs taken out for biochemical and enzymatic analysis. For the determination of enzyme activity, liver, muscle and brain were dissected out, and $5 \%$ homogenate was prepared in chilled sucrose solutions $(0.25 \mathrm{M})$ in a mechanical tissue homogenizer. The homogenate was centrifuged at $5,000 \mathrm{~g}$ at $4{ }^{\circ} \mathrm{C}$ for $10 \mathrm{~min}$, supernatant collected and stored at $-20^{\circ} \mathrm{C}$ for further analysis. Blood was collected by puncturing the caudal vein using a medical syringe (No. 23), which was previously rinsed with $2.7 \%$ EDTA solution (as an anticoagulant) and shaken gently in order to prevent hemolysis of blood.

\section{Biochemical studies}

Glucose was estimated from the blood, brain and muscle of the fish using arsenomolybdate reagent by the method of Nelson and Somogyi (1945). For glucose, the blood was deproteinized (v/v) with zinc sulfate and barium hydroxide, centrifuged at 5,000 $\mathrm{g}$ for $5 \mathrm{~min}$, and the supernatant was used for the estimation of glucose. Tissue homogenates were used for the estimation of glucose from brain and muscle. Glycogen content was estimated from the liver and muscle of the fish using anthrone reagent as described by Hassid and Abraham (1957). Ascorbic acid content in the kidney and brain tissues was determined using 2,4-dinitro-phenylhydrazine at $540 \mathrm{~nm}$ according to the method described by Roe and Keuther (1943). UV-VIS spectrophotometer (E-Merck, Germany) was used for determination of optical density. 
Enzyme assay

Acetylcholine esterase (AchE; EC 3.1.1.7) was assayed by the method described by Hestrin (1949), using a mixture of $0.07 \mathrm{M}$ phosphate buffer ( $\mathrm{pH} 7.2), 4 \mathrm{mM}$ acetylcholine ( $\mathrm{pH} 4.0)$, substrate-buffer mixture (1/10 dilution) and $0.2 \mathrm{ml}$ of tissue homogenate. The mixture was incubated at $37{ }^{\circ} \mathrm{C}$ for $30 \mathrm{~min}$, and the OD (optical density) was recorded at $540 \mathrm{~nm}$. Alkaline phosphatase activity was determined by the method of Garen and Levinthal (1960). The assay mixture consisted of $0.2 \mathrm{ml}$ bicarbonate buffer $(0.2 \mathrm{M})$, $0.1 \mathrm{ml}$ of $0.1 \mathrm{M} \mathrm{MgCl}_{2}, 0.05 \mathrm{ml}$ tissue homogenate, $0.5 \mathrm{ml}$ of distilled water and $0.1 \mathrm{ml}$ of freshly prepared $0.1 \mathrm{M}$ para-nitrophenyl phosphate. The reaction mixture was incubated in water bath at $37{ }^{\circ} \mathrm{C}$ for $15 \mathrm{~min}$, and the reaction was stopped by $1.0 \mathrm{ml}$ of $0.1 \mathrm{~N} \mathrm{NaOH}$. $\mathrm{OD}$ was taken at $410 \mathrm{~nm}$. Total adenosine triphosphatase (ATPase; EC 3.6.1.3) was assayed in a reaction mixture of $0.1 \mathrm{M}$ Tris- $\mathrm{HCl}$ buffer (pH 7.8), $100 \mathrm{mM} \mathrm{NaCl}, 20 \mathrm{mM}$ $\mathrm{KCl}, 3 \mathrm{mM} \mathrm{MgCl} 2,5 \mathrm{mM}$ ATP and $0.1 \mathrm{ml}$ tissue homogenate. The mixture was incubated for $15 \mathrm{~min}$, and the reaction was terminated by means of $10 \%$ TCA (Post and Sen 1967). Phosphate liberated was estimated at $660 \mathrm{~nm}$ (Fiske and Subbarow 1925). Lactate dehydrogenase ( $\mathrm{LDH} ; \mathrm{EC}_{1} .1 .1 .27$ ) was assayed using $0.2 \mathrm{mM} \mathrm{NADH}$ solution in $0.1 \mathrm{M}$ phosphate buffer ( $\mathrm{pH} 7.5$ ) and $0.1 \mathrm{ml}$ tissue homogenate (after 10 times dilution of the homogenate). The reaction was initiated by adding $0.2 \mathrm{mM}$ sodium pyruvate as the substrate, and OD recorded at $340 \mathrm{~nm}$ for $3 \mathrm{~min}$ at an interval of $30 \mathrm{~s}$ (Wroblewski and Ladue 1955).

Data analysis

The data obtained in the present experiment were subjected to one-way ANOVA using Statistical Package, SPSS version 11. Duncan's multiple range tests were used to determine the differences among treatment mean, which were significant at $P<0.05$. For growth analysis, two-way ANOVA was conducted taking into consideration the monthly weight gain in different salinities.

\section{Results}

Data pertaining to average water quality parameters of the rearing media of C. batrachus are presented in Table 1. All parameters like temperature, dissolved oxygen (DO), turbidity, $\mathrm{pH}$ and salinity is within the acceptable limit for culturing fishes. In the rearing media, though we have mentioned as $0 \%$ but actual concentration of the salinity was $0.26 \%$ only.

Growth and survival

Data pertaining to growth and mortality of $C$. batrachus are presented in Figs. 1 and 2. There was no significant difference $(P>0.05)$ in weight gain among the fishes exposed to different salinities. However, weight gain in each month was statistically significant $(P<0.05)$. The sublethal salinity exposure of $C$. batrachus for 90 days caused a reduction in the weight gain $(P>0.05)$ compared to control. At the end of rearing period, the weight gain observed at 0,4 and $8 \%$ salinity were $62.7,57.8$ and $54.5 \%$, respectively. The survival rate also decreased at higher salinity $(P>0.05)$. At the end of 90 days, the survival rate in the corresponding experiments was $96.7,93.3$ and $83.3 \%$, respectively. 


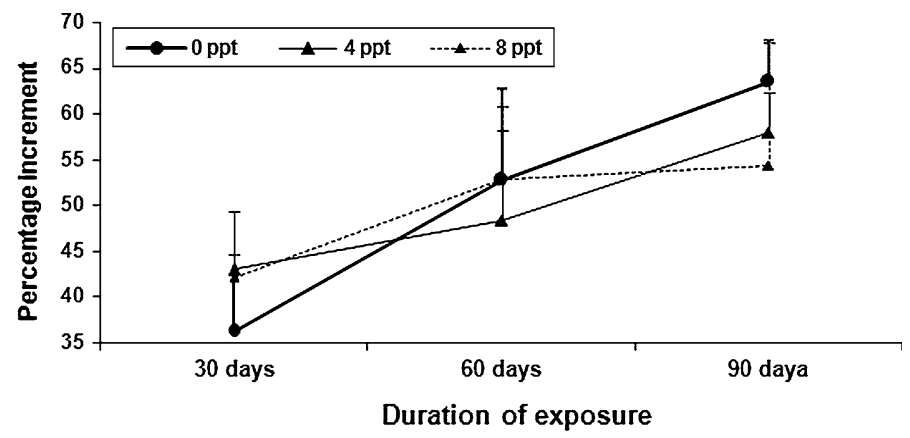

Fig. 1 Percentage weight gain C. batrachus exposed to different salinities for a period of 90 days

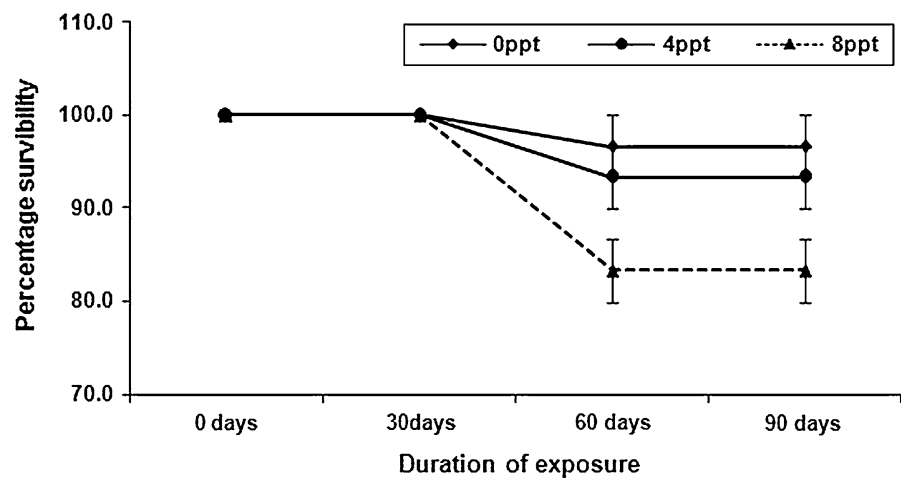

Fig. 2 Percentage survival of $C$. batrachus exposed to different salinities for a period of 90 days of rearing

Glucose

Glucose level was estimated in blood, brain and muscle of $C$. batrachus at the end of 90-day rearing period (Fig. 3). There was a significant $(P<0.05)$ difference in blood glucose level in $C$. batrachus exposed to sublethal dose of salinity compared with $0 \%$ salinity level. Blood glucose level was increased by $29.11 \%$ at $4 \%$ salinity and decreased by $28.8 \%$ at $8 \%$ o salinity compared to control at the end of 90 days. However, there was no difference in blood glucose level between control and $4 \%$ and between 4 and $8 \%$. Brain glucose levels were also significantly reduced $(P<0.05)$ in fishes exposed to medium levels of salinity. At the end of 90-day rearing period, 37.0 and $19.83 \%$ reduction in glucose level was observed in comparison with control at 4 and $8 \%$ salinity; although no significant $(P>0.05)$ difference was found between 4 and $8 \%$ (Fig. 3). In fish muscle, the glucose levels were not significantly $(P>0.05)$ affected by the treatments when exposed to salinity stress.

\section{Glycogen}

Glycogen level was estimated in liver and muscle tissues of $C$. batrachus after 90 days of exposure to salinity (Fig. 4). There was a significant decrease $(P<0.05)$ in the glycogen level in liver tissues after 90 days. Reduction of glycogen in liver was 48.2 and $45.8 \%$ at 4 and $8 \%$ salinity, respectively, compared with the control. However, in muscle tissue, the glycogen level was not significantly $(P>0.05)$ affected by the salinity. 


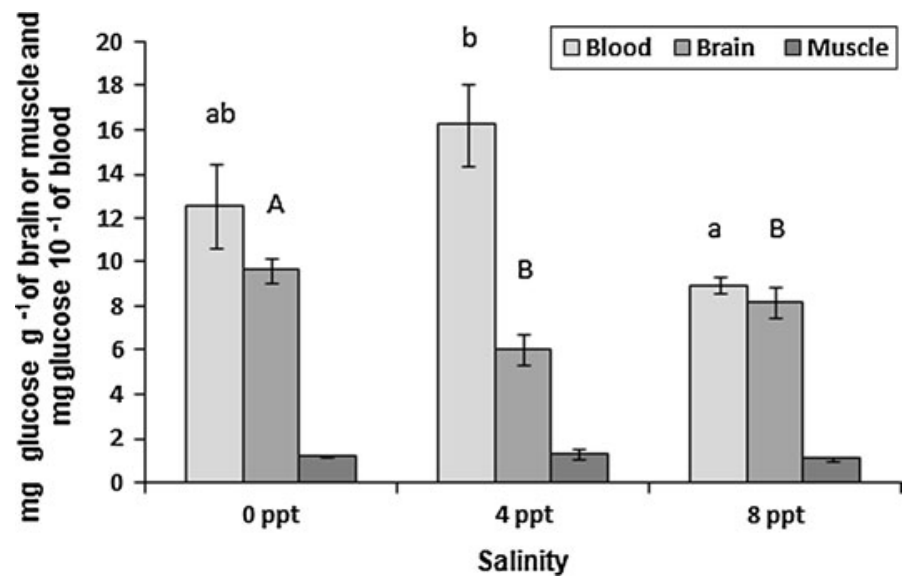

Fig. 3 Glucose level in different organs of Clarias batrachus exposed to different salinities at the end of 90 days of rearing. Data are expressed as mean \pm SE, $n=5$. Bar with different alphabet letters ( $a$ and $b$ for blood, $A$ and $B$ for brain) differ significantly $(P<0.05)$

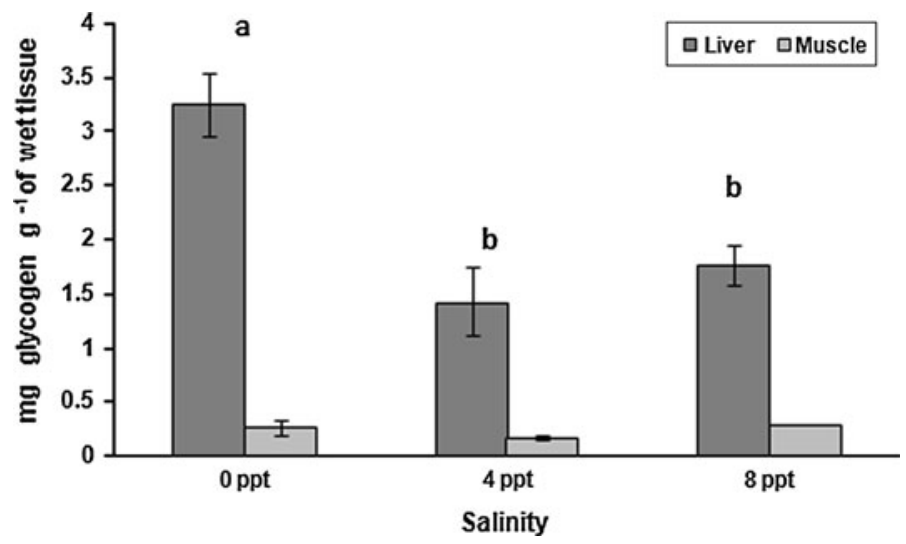

Fig. 4 Glycogen level in liver and muscle of Clarias batrachus exposed to different salinities at the end of 90 days of rearing. Data are expressed as mean $\pm \mathrm{SE}, n=5$. Bar with different alphabet letters ( $a$ and $b$ for liver) differ significantly $(P<0.05)$

Ascorbic acid

Ascorbic acid level was found to be significantly $(P<0.05)$ reduced after 90 days of exposure in liver, kidney, brain and muscle (Fig. 5). It reduced by 15.70 and $31.07 \%$ in liver; by 17.64 and $34.38 \%$ in kidney; by 35.67 and $46.22 \%$ in brain and by 13.79 and $22.70 \%$ in muscle at 4 and $8 \%$ salnity, respectively, after 90 days of exposure.

Enzyme activity

Data pertaining to different enzymatic activities in $C$. batrachus are presented in Table 2. AchE activity in brain tissues of $C$. batrachus exposed to different salinities indicated that activity decreased progressively $(P<0.05)$ when salinity was increased from 0 to $8 \%$ o 


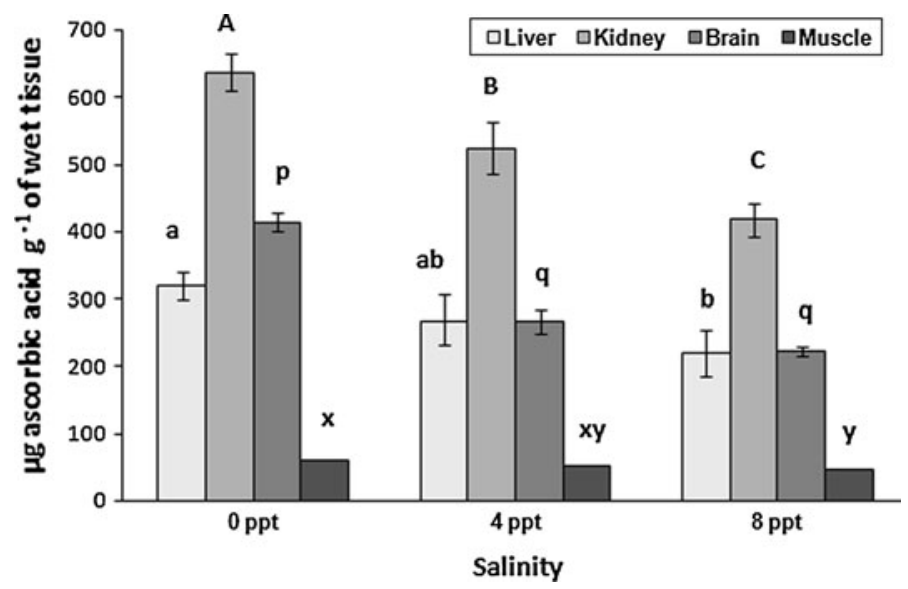

Fig. 5 Ascorbic acid level in different tissues of Clarias batrachus exposed to different salinities at the end of 90 days of rearing. Data are expressed as mean $\pm \mathrm{SE}, n=5$. Bar with different alphabet letters ( $a$ and $b$ for brain, $A, B$ and $C$ for kidney, $p$ and $q$ for brain, $\mathrm{x}$ and y for muscle) differ significantly $(P<0.05)$

salinity. Inhibition of AchE to the extent of 39.3 and $54.45 \%$ was recorded at 4 and $8 \%$ salinity ALP in liver $(P<0.05)$ and muscle $(P>0.05)$ of $C$. batrachus also showed a decreasing trend with increasing salinity. In muscle, ALP activity was reduced by 30.8 and $49.3 \%$ at 4 and $8 \%$, respectively, compared with the control value, while in liver, it was 35.15 and $67.19 \%$ lower at the same salinities. The ATPase activity in liver and muscle of C. batrachus also showed a decreasing $(P<0.05)$ trend with increasing salinity. A 55.6 and $60 \%$ reduction at liver tissues, 43.5 , and $51 \%$ reduction in the muscles corresponding to 4 and $8 \%$ salinity were recorded at the end of 90-day rearing period. LDH activity was also significantly $(P<0.05)$ affected in the muscle tissues at the end of 90 days of exposure, and at the end of 90 days, 33.4 and $8.82 \%$ reduction corresponding to 4 and $8 \%$ salinity were recorded. The muscle LDH activity was higher at $8 \%$ compared to 4 salinity. Though LDH activity in liver tissues was not significantly $(P>0.05)$ affected but its activity was reduced at both the salinity levels ( 7 and $9.7 \%$ at 4 and $8 \%$, respectively).

\section{Discussion}

The present study revealed that the growth of Clarias batrachus is affected by salinity. This finding is similar to the earlier reports in Tilapia rendalli (Kang'ombe and Brown 2008), Mystus vittatus (Arunachalam and Ravichandra Reddy 1978), Oreochromis niloticus (Schofield et al. 2010) and Cyprinus carpio fingerlings (Wang et al. 1996). Survival rate of $C$. batrachus was also reduced at higher salinities. Low survival rates of C. batrachus at higher salinity were comparable to those reported in Rainbow trout by McKay and Gjerde (1985). De-Boeck et al. (2000) reported that salt exposure reduced food intake by $70 \%$ in C. carpio and had adverse effect on growth and survival in fishes.

In the present study, blood glucose level was higher at $4 \%$ salinity compared with control (0 \%), indicating hyperglycemic condition in C. batrachus. Stress in fish has been shown to cause a primary response, involving neuro-hormonal stimulation resulting in an increase in corticosteroid and catecholamine secretions (Karşi and Yildiz 2005). These primary stress responses cause a number of physiological changes known as 'secondary 
Table 2 Enzymatic activities in different organs of Clarias batrachus exposed to salinities at the end of 90 days of culture period

\begin{tabular}{|c|c|c|c|c|}
\hline \multirow[t]{2}{*}{ Parameters } & \multirow[t]{2}{*}{ Organs } & \multicolumn{3}{|l|}{ Salinity } \\
\hline & & $0 \%$ & $4 \%$ & $8 \%$ \\
\hline AChE activity & Brain & $0.168 \pm 0.03^{\mathrm{a}}$ & $0.102 \pm 0.02^{\mathrm{a}, \mathrm{b}}$ & $0.076 \pm 0.01^{b}$ \\
\hline \multirow[t]{2}{*}{ ALP activity } & Muscle & $2.900 \pm 0.37$ & $2.005 \pm 0.68$ & $1.467 \pm 0.54$ \\
\hline & Liver & $16.773 \pm 1.32^{\mathrm{a}}$ & $10.876 \pm 0.75^{\mathrm{b}}$ & $5.737 \pm 0.96^{\mathrm{c}}$ \\
\hline \multirow[t]{2}{*}{ ATP activity } & Muscle & $1.358 \pm 0.18^{\mathrm{a}}$ & $0.766 \pm 0.07^{b}$ & $0.665 \pm 0.17^{\mathrm{b}}$ \\
\hline & Liver & $1.958 \pm 0.41^{\mathrm{a}}$ & $0.868 \pm 0.07^{\mathrm{b}}$ & $0.783 \pm 0.13^{\mathrm{b}}$ \\
\hline \multirow[t]{2}{*}{ LDH activity } & Muscle & $160.724 \pm 14.73^{\mathrm{a}}$ & $106.948 \pm 21.69^{\mathrm{b}}$ & $146.448 \pm 7.36^{\mathrm{b}}$ \\
\hline & Liver & $42.762 \pm 6.13$ & $39.728 \pm 6.72$ & $38.580 \pm 1.37$ \\
\hline
\end{tabular}

Data are expressed as mean $\pm \mathrm{SE}(n=5)$. Different superscript, lower case letters $(\mathrm{a}, \mathrm{b}, \mathrm{c})$ in the same row indicate significant difference (Duncan's multiple range test, $P<0.05$ ). Enzyme activities are expressed as follows: ACHE, $\mu$ moles of acetyl choline hydrolyzed $/ \mathrm{mg}$ protein/minute at $37{ }^{\circ} \mathrm{C}$; ALP, n moles of paranitrophenol released/mg protein/minute at $37^{\circ} \mathrm{C}$; ATPase: enzyme activity expressed in $\mu \mathrm{g}$ of phosphorus released $/ \mathrm{mg}$ protein $/$ minute at $37{ }^{\circ} \mathrm{C} ; \mathrm{LDH}, \Delta 0.01 \mathrm{OD} / \mathrm{mg}$ protein $/$ minute at $25^{\circ} \mathrm{C}$

effects' (Foo and Lam 1993). Increased plasma glucose level is used as an indicator of the secondary stress response (Mommsen et al. 1999). Jeanette et al. (2007) recorded significant increase in plasma glucose levels in Oreochromis mossambicus with the increase in salinity, which they attributed to the stress response and/or increased energy demand for maintenance of hydro-mineral balance at higher salinity. However, in the present study, blood glucose level was lower at $8 \%$ salinity, which could be attributed to the higher utilization of glucose (Martínez-Álvarez et al. 2002) and might be due to reduced appetite of the fishes at higher salinity (Usher et al. 1991; Plaut 1998). In brain, there was significant decrease $(P<0.05)$ in glucose level both at 4 and $8 \%$ salinity. Brain generally requires only glucose for energy purpose and reduced glucose flow into the brain at higher salinity might be due to the compensatory mechanism developed by the species to combat stress. During stress, demand of glucose in different tissues is higher in order to supply the energy for osmoregulatory mechanisms (Krumschnabel and Lackner 1993; Plaut 1998), whereupon glyconeogenesis even increases (Jürss and Bittorf 1990). However, reduced glucose supply to the brain might have detrimental effect on brain tissue.

In the present study, glycogen level in liver tissues significantly reduced $(P<0.05)$, indicating high rate of catabolism. Similar to the present study, depletion of liver glycogen was recorded in C. carpio when exposed to salt stress (De-Boeck et al. 2000) and in liver tissue of C. batrachus exposed to pesticides stress (Begum 2004). The results reveal that at higher salinity fish might have performed high rate of glycogenolysis activity to meet highenergy demand and that resulted in reduced glycogen levels in liver. Stress-associated hyperglycemia is an expected result of stress or exhaustive exercise in fishes (Barton and Iwama 1991; Hrubec et al. 1997). Chan and Woo (1978) reported that cortisol has shown to promote catabolism of peripheral tissues through increased gluconeogenesis leading to hyperglycemia.

Antioxidant vitamin C is well known for its major antistress activity (Azad et al. 2007, Misra et al. 2007; Norouzitallab et al. 2009). The antioxidant activity of ascorbic acid is based on its ability to react with free radicals. Most fish species cannot synthesize ascorbic acid and have to depend on external source to meet their needs (Chatterjee et al. 1975). In fish, liver and head kidney are the most significant storage organs for vitamin $\mathrm{C}$ (Gabaudan 
and Verlhac 1992). Heath (1995) reported a reduction in the level of vitamin C in fish subjected to sublethal levels of organic and inorganic substances. In the present study, vitamin $\mathrm{C}$ level reduced significantly $(P<0.05)$ in all the organs under study with an increase in salinity (Fig. 5). The reduction in the ascorbic acid level might be due to high rate of utilization of vitamin $\mathrm{C}$ at higher salinity. Reduction of vitamin $\mathrm{C}$ in fish due to different pesticides has been reported in many fish (Madhuban and Kaviraj 2003, 2009; Sarma et al. 2010b; Sarma et al. 2009). Madhuban and Kaviraj (2009) opined that depletion of ascorbic acid is probably a defensive reaction of fish to combat stress, which thus enhances the requirement of ascorbic acid during stress. In the present study, vitamin C might have been used up for detoxification process (Mauck et al. 1978) or might have been used up for preventing peroxidation of cells (Winston and Di-Guilo 1991), which in turn might have caused a functional reduction in vitamin $\mathrm{C}$ content in different tissues thereby exposing the tissue to possible cell injury.

Acetylcholine esterase (AchE) is one of the most widely used enzymes as a biomarker for environmental pollution (Sarma et al. 2010b). In the present study, AchE activity in the brain of $C$. batrachus was inhibited significantly (39.3 at $4 \%$ and 54.45 at $8 \%$ ) with increasing salinity. Reduction in AchE enzyme activity indicates an accumulation of acetylcholine in the brain tissue, interfering with energy metabolism of the nervous system, preventing transmission of nervous impulses, and thereby causing behavioral alteration (Sarma et al. 2010b). It has been reported that fish can tolerate the loss of AchE activity up to $70-80 \%$ before death (Coppage and Mathew 1974). Pavlov (1996) reported 75 and $70.6 \%$ inhibition of AchE activity in tilapia and perch respectively when they were exposed to acute salinity stress. As high as $79.03 \%$ inhibition of AchE activity was observed in $C$. batrachus exposed to pesticides (Yadav et al. 1998). In another study, 55-62\% inhibition of brain AchE activity was recorded in Girardinichthys viviparous, exposed to polluted water (López-López et al. 2006).

The ALP activities in liver and muscle were also inhibited at higher salinities. Similar to the present study, $27 \%$ inhibition of ALP activity in liver tissues of Oreochromis mossambicus was reported by Rao (2006) when exposed to insecticides. Reduction of ALP was also reported in Heteropneustes fossilis (Johal et al. 2002) and Clarias gariepinus (Madhuban and Kaviraj 2009) upon different stressors. Madhuban and Kaviraj (2009) opined that the decrease of alkaline phosphatase activity might result in altered cell membrane transport, decrease in glycogen level and inhibitory effect on cell growth and proliferation. In the present study, the inhibition of ALP in C. batrachus might be due to continuous exposure to higher salinity, which causes depression in the overall impact of the enzyme.

Adenosine triphosphatase (ATPases) are membrane-bound enzymes involved in the immediate release of energy which are responsible for a large part of basic metabolic and physiological activities (Smitha and Philip 2011). Measurement of ATPases could also be used as a surrogate biomarker to assess the exposure to chemical pollutants (Parveza et al. 2006). In the present study, it was found that the activity of ATPase was reduced in liver and muscle of $C$. batrachus when exposed to salinity for a period of 90 days. The reduction in ATPase activity could indicate the alterations in the structure and functions of the membrane or may be due to direct inhibition of long-term exposure to high salinity on the enzymes. ATPase is related to immediate release of energy, and reduction in its activity might have significantly affected the fishes in terms of the energy balance and ion transport (Sarma et al. 2010b). Reduction in ATPase activity after the exposure to various stressors has been reported earlier in C. batrachus (Begum 2009), O. mossambicus (Smitha and Philip 2011) and Channa punctata (Parveza et al. 2006). Rao and Rao (1983) reported 
reduced ATPase activity in Tilapia mossambica exposed to methyl parathion suggesting the inhibition of active transport system and oxidative phosphorylation.

The LDH is the terminal enzyme of glycolytic pathway and used extensively as a biomarker for various environment-monitoring programmes. In the present study, LDH activity in liver tissue was also reduced with increasing salinity as observed by Agrahari and Gopal (2009) in Channa punctatus when exposed to monocrotophos. It was attributed to the high rate of glycolysis, which is the only energy-producing pathway for the animals under stress. Rao (2006) reported $25 \%$ inhibition in muscle LDH activity in $O$. mossambicus exposed to insecticides. In the present study, the reduction in LDH activity was higher at $4 \%$ othan at $8 \%$ salinity $(P>0.05)$. Lower muscle LDH activity in fish at $4 \%$ might be due to faster rate of glycolysis, LDH is a marker enzyme of tissue damage and elevated LDH activity is reported to cause liver necrosis (Ramesh et al. 1993).

From the present investigation, it can be summarized that long-term exposure to salinity affects the growth and biochemical composition of tissues in C. batrachus. It may be presumed that the impact of salinity on weaker and younger fishes may be many folds higher than the subadult individuals of $C$. batrachus, as used in this study. Hence, a comprehensive study to assess the impact of higher salinity on different freshwater species across the life stages would throw more light on the extent of vulnerability of different fishes to the situations linked to climate change and provide necessary guidelines in the selection of suitable fishes for aquaculture in low saline brackishwater areas.

Acknowledgments The authors are grateful to the Director, Central Agricultural Research Institute, Port Blair for providing the facilities during this study.

\section{References}

Agrahari S, Gopal K (2009) Fluctuations of certain biochemical constituents and markers enzymes as a consequence of monocrotophos toxicity in the edible freshwater fish, Channa punctatus. Pestic Biochem Phys 94:5-9

APHA (1998) In: Clesceri LS, Greenberg AE, Eaton AD (eds) Standard methods for the examination of water and wastewater, 20th edn. American Public Health Association, American Water Works Association, Water Environment Federation, Washington, DC

Arunachalam S, Ravichandra Reddy S (1978) Food intake, growth, food conversion, and body composition of catfish exposed to different salinities. Aquaculture 16:163-171

Azad IS, Dayal JS, Poornima M, Ali SA (2007) Supra dietary levels of vitamins C and E enhance antibody production and immune memory in juvenile milkfish, Chanos chanos to formalin-killed Vibrio vulnificus. Fish Shellfish Immunol 23:154-163

Barton BA, Iwama GK (1991) Physiological changes in fish from stress in aquaculture with emphasis on the response and effects of corticosteroids. Ann Rev Fish Dis 1:3-26

Begum G (2004) Carbofuran insecticide induced biochemical alterations in liver and muscle tissues of the fish Clarias batrachus(Linn) and recovery response. Aquat Toxicol 66:83-92

Begum G (2009) Enzymes as biomarkers of cypermethrin toxicity: response of Clarias batrachus tissues ATPase and glycogen phosphorylase as a function of exposure and recovery at sublethal level. Toxicol Mech Method 19(1):29-39

Boyd CE, Tucker CS (1998) Pond aquaculture water quality management. Kluwer, London, p 700

CAMP (Conservation Assessment and Management Plan) (1998) Executive summary report on freshwater fishes of India. National Bureau of Fish Genetic Resources, Lucknow and Zoo Outreach Organisation, Coimbatore, pp 1-10

Chan DKO, Woo NYS (1978) Effect of cortisol on the metabolism of eel, Anguilla japonica. Gen Comp Endocrinol 35:205-215

Chatterjee IB, Majunmder AK, Nandi BK, Subramanian N (1975) Synthesis and major functions of vitamin $\mathrm{C}$ in animals. Ann NY Acad Sci 258:24-48

Chondor SL (1999) Biology of finfish and shell fish. SCSC publishers, India, pp 422-434 
Coppage DO, Mathew E (1974) Short-term effects of organophosphate pesticides on cholinesterases of estuarine fishes and pink shrimp. Bull Environ Contam Toxicol 11:483-488

Cruz EM, Rhidha M, Abdullah MS (1990) Production of African freshwater tilapia O. spilurus (Gunther) in seawater. Aquaculture 84:41-48

Das SK (2002) Seed production of Magur (Clarias batrachus) using a rural model portable hatchery in Assam, India - a farmer proven technology. Aquac Asia 7(2):19-21

De-Boeck G, Vlaeminck AG, Van-Der Linden A, Blust R (2000) The energy metabolism of common carp (Cyprinus carpio) when exposed to salt stress: an increase in energy expenditure or effects of starvation? Physiol Biochem Zool 73(1):102-111

Deshmukh PS, Din M (2008) Site selection and construction of broad bed and furrow system. In: Ravisankar M, Ambast SK, Srivastava RC (eds) Crop diversification through broad bed and furrow system in coastal region, Central Agricultural Research Institute Port Blair, pp 15-20

Fiske CH, Subbarow Y (1925) The colorimetric determination of phosphorus. J Biol Chem 66:375-400

Foo JTW, Lam TJ (1993) Serum cortisol response to handling stress and the effect of cortisol implantation on testosterone level in tilapia, Oreochromis mossambicus. Aquaculture 115:145-158

Gabaudan J, Verlhac V (1992) Biological efficacy of Rovimix Stay-C as a source of vitamin C for Salmonids. Poster presentation at the International Symposium on Cultivation of Atlantic salmon 16-20.08 1992. Bergen, Norway

Garen A, Levinthal CA (1960) Fine-structure genetic and chemical study of the enzyme Alkaline phosphatase of E. coli. I. Purification and characterization of Alkaline phosphatase. Biochem Biophys Acta 38:470

Hassid WJ, Abraham S (1957) Chemical procedures for analysis of polysaccharides In: Calowick SP, Kaplan NO (eds) Methods in enzymology vol. III. Academic Press Inc, New York, pp 35-36

Heath AG (1995) Water pollution and fish physiology, 2nd edn. Lewis publishers, London 359

Hestrin L (1949) The reaction of Acetyl choline esters and other carboxylic acid derivatives with hydroxylamine and its analytical application. J Biol Chem 180:249-261

Hora SL, Pillay TVR (1962) Handbook on fish culture in the Indo- Pacific region. FAO Fish Boil tech pap no. 14, p 204

Hrubec TC, Robertson JL, Smith SA (1997) Effects of temperature on hematologic and serum biochemical profiles of hybrid striped bass (Morone chrysops x Morone saxatilis). Am J Vet Res 58:126-130

Jayaram KC (1981) The freshwater fishes of India, Pakistan, Bangladesh, Burma and Sri Lanka. Zoological Survey of India, Calcutta, p 475

Jeanette CF, Kunkel-Patterson A, Mathias L, Riley LG, Yancey PH, HiranoT, Grau EG (2007) Effects of environmental salinity and temperature on osmoregulatory ability, organic osmolytes, and plasma hormone profiles in the Mozambique tilapia (Oreochromis mossambicus). Comp Biochem Physiol 146A:252-264

Johal MS, Sandhu GS, Kaur R (2002) Effect of fenvalerate on acid and alkaline phospharase activity in certain tissues of Heteropneustes fossilis (Bloch). Poll Res 21(3):309-313

Jürss K, Bittorf T (1990) The relationship between biochemical liver status and growth in immature rainbow trout (Salmo gairdneri Richardson). Effects of feeding and salinity. Zool J Physiol 94:474-485

Kang'ombe J, Brown JA (2008) Effect of Salinity on growth, feed utilization, and survival of Tilapia rendalli under laboratory conditions. J Appl Aquac 20(4):256-271

Karşi A, Yildiz HY (2005) Secondary stress response of nile tilapia, Oreochromis niloticus, after direct transfer to different salinities. Tarim Bilimleri Dergisi 11(2):139-141

Khedkar GD, Reddy ACS, Persis M, Kondadhasula R, Kshitish M (2010) Clarias batrachus (Linn.1758) population is lacking genetic diversity in India. Mol Biol Rep 37:1355-1362

Kilambi RV, Zdinak A (1980) The effect of acclimation on the salinity tolerance of grass carp, Ctenopharyngodon idella (Cuv. and Val.). J Fish Biol 6:171-175

Krumschnabel G, Lackner R (1993) Stress responses in rainbow trout Oncorhynchus mykiss alevins. Comp Biochem Physiol 104A:777-784

Kumar A, Sharma B, Pandey RS (2012) Alterations in nitrogen metabolism in freshwater fishes, Channa punctatus and Clarias batrachus, exposed to a commercial-grade $\lambda$-cyhalothrin, REEVA-5. Intel $\mathrm{J}$ of Exp Path 93(1):34-45

López-López E, Sedeño-Díaza JE, Perozzib F (2006) Lipid peroxidation and Acetylcholinesterase activity as biomarkers in the black sailfin goodeid, Girardinichthys viviparous (Bustamante) exposed to water from Lake Xochimilco (Mexico). Aquat Ecosyst Health 9(3):379-385

Madhuban DB, Kaviraj A (2003) Ascorbic acid supplementation of diet for reduction of deltamethrin induced stress in freshwater catfish, Clarias gariepinus. Chemosphere 53:883-888 
Madhuban B, Kaviraj A (2009) Toxicity of the pyrethroid pesticide fenvalerate to freshwater catfish Clarias gariepinus: Lethality, biochemical effects and role of dietary ascorbic acid. J Environ Sci Heal 44 B:578-583

Malik R, Sirohi SK (2004) Applied animal nutrition research techniques. National Dairy Research Institute. Karnal, p 210

Martínez-Álvarez M, Hidalgo MC, Domezain A, Morales AE, García-Gallego M, Sanz A (2002) Physiological changes of sturgeon Acipenser naccarii caused by increasing environmental salinity. J Exp Biol 205:3699-3706

Mauck WL, Mehrle PM, Mayer FL (1978) Effect of polychlorinated biphenyl Arochor@1254 on growth, survival and bone development in brook trout, Salvelinus fontinalis. J Fish Res Board Can 35: 1084-1088

McKay LR, Gjerde B (1985) The effect of salinity on growth of rainbow trout. Aquaculture 49:325-331

Misra CK, Das BK, Mukherjee SC, Pradhan J (2007) Effects of dietary vitamin C on immunity, growth and survival of Indian major carp Labeo rohita, fingerlings. Aquacult Nutr 13:35-44

Mommsen TP, Vijayan M, Moon TW (1999) Cortisol in teleosts: dynamics, mechanisms of action, and metabolic regulation. Rev Fish Biol Fish 9:211-268

Nelson N, Somogyi M (1945) Cited by Oser BL (1965). In: Hawk's physiological chemistry, 14th edn. McGraw Hill, New York

Norouzitallab P, Farhangi M, Babapour M, Rahimi R, Sinha AK, Baruah K (2009) Comparing the efficacy of dietary a-tocopherol with that of DL-a-tocopheryl acetate, both either alone or in combination with ascorbic acid, on growth and stress resistance of angelfish, Pterophylumscalare, juveniles. Aquacult Int 17(3):207-216

Parveza S, Sayeedb I, Raisuddin S (2006) Decreased gill ATPase activities in the freshwater fish Channa punctata (Bloch) exposed to a diluted paper mill effluent. Ecotoxicol Environ Saf 65(1):62-66

Pavlov DF (1996) Stress-induced dynamics of fish brain Acetyl choline esterase activity, p. 6. http:// www-heb.pac.dfo-mpo.gc.ca/congress/1996/Applied/pavlov1.pdf. Accessed latest on 10 April 2012

Plaut I (1998) Comparison of salinity tolerance and osmoregulation in two closely related species of blennies from different habitats. Fish Physiol Biochem 19:181-188

Post RL, Sen AK (1967) Sodium and potassium stimulated ATPase. In: Colowick SP, Kaplan NO (eds) Methods in enzymology, vol 10. Academic Press, New York, pp 762-768

Raja R, Ghoshal Chaudhuri S, Ravisankar N, Swarnam TP, Jayakumar V, Srivastava RC (2009) Salinity status of tsunami-affected soil and water resources of South Andaman, India. Curr Sci 96:152-156

Ramesh M, Sivakumari K, Kanagaraj MK, Manavalaramanujam K (1993) Toxicity of dye effluent in lactate dehydrogenase activity in Labeo rohita. J Environ Prot 13:124-127

Rao JV (2006) Biochemical alterations in euryhaline fish, Oreochromis mossambicus exposed to sub-lethal concentrations of an organophosphorus insecticide, monocrotophos. Chemosphere 65(10):1814-1820

Rao SPK, Rao RKV (1983) Tissue specific alteration of aminotransferases and total ATPases in the fish (Tilapia mossambica) under methyl parathion impact. Toxicol Lett 20(1):53-57

Reish DL, Oshida PA (1987) Manual of method in aquatic environment research, Part 10_-short term static bioassay. FAO Fisheries Technical Paper. 247. FAO, Rome, pp 1-62

Roe JH, Keuther CA (1943) The determinations of ascorbic acid in whole blood and urine through the 2,4dinitrophenylhydrazine (DNPH) derivative of dehydroascorbic acid. J Biol Chem 147:399-407

Sahoo SK, Giri SS, Chandra S (2010) Threatened fishes of the world: Clarias batrachus. Environ Biol Fish 88:85-86

Sarma K, Pal AK, Sahu NP, Ayyappan S, Baruah K (2009) Dietary high protein and vitamin C mitigates endosulfan toxicity in Channa punctatus. Sci Total Environ 407(12):3668-3673

Sarma K, Pal AK, Sahu NP, Mukherjee SC, Baruah K (2010a) Biochemical and histological changes in the brain tissue of spotted murrel, Channa punctatus (Bloch), exposed to endosulfan. Fish Physiol Biochem 36(3):597-603

Sarma K, Ravisankar N, Dam Roy S, Grinson G, Srivastava RC (2010b) Prospects of fish culture in the broad bed and furrow system in Andaman: a case study. Environ Ecol 28(1):86-90

Schofield PJ, Peterson MS, Lowe MR, Brown-Peterson N, Todd SW, Gregoire DR, Langston JN (2010) Effects of salinity on survival, growth and reproduction of non-native Nile tilapia (Oreochromis niloticus) from southern Mississippi. USGS

Smitha VB, Philip B (2011) Effect of ethanol on branchial adenosine triphosphatases in Oreochromis mossambicus (Peters). Toxicol Int 18(1):27-30

Suresh RV, Lin CK (1992) Tilapia culture in saline waters: review. Aquaculture 106:201-226

Usher ML, Talbot C, Eddy FB (1991) Effects of transfer to seawater on growth and feeding in Atlantic salmon smolts (Salmo salar L.). Aquaculture 94:309-326 
Verma V, Prasad Y, Singh BR (2011) Effect of pH and salinity on pathogenicity of Flavobacterium columnare and Myxobacterium sp. in Indian cat fish, Clarias batrachus (Linn.) and Heteropneustes fossilis (Bloch.). J Environ Biol 32:573-577

Wang J-Q, Lui H, Po H, Fan L (1996) Influence of salinity on food consumption, growth and energy conversion efficiency of common carp (Cyprinus carpio) fingerlings. Aquaculture 148:115-124

Watanabe WO, Clark JH, Dunham JB, Wicklund RI, Olla BL (1990) Culture of Florida red tilapia in marine cages: the effect of stocking density and dietary protein on growth. Aquaculture 90:123-134

Winston GW, Di-Guilo RT (1991) Prooxidant and antioxidant mechanisms in aquatic organisms. Aquat Toxicol 19:137-161

Wroblewski L, Ladue JS (1955) LDH activity in blood. Proc Soc Exp Biol Med 90:210-213

Yadav A, Singh RK, Sharma B (1998) Interaction of carbofuron with the Acetylcholine esterase from the brain of the teleost, Clarias batrachus. Toxicol Environ Chem 65:245-254 